\title{
Creative Tourism and Business Development in Akwa Ibom State
}

\author{
Christabel D. Brownson
}

\section{ABSTRACT}

Creative Tourism is a new tourism opportunity that emphasizes the engagement between host and guests who are interested in actively participating in and learning from an authentic experience. It is the future of cultural tourism. Although it is considered as an escape route from the reproduction of cultural assets of tourism destination, contributing the preserve of original cultures and intangible heritage. A simple evaluation of the performance of the Nigerian Tourism industry reveals the absence of a tourism spirit among industry players and the lack of adequate visitor ready tourism products. Despite the low contribution of tourism to the national GDP of the Country, the Nigerian government has made several efforts and attempts to boost the industry with sporadic developments in some states of the country of which Akwa Ibom State is one of them. It is with this view that this study seeks to investigate Creative tourism and business development in Akwa Ibom State. Using a quantitative analysis, a total sample of 192 entrepreneurs were investigated. Findings revealed that Creative Tourism relates positively with business development in Akwa Ibom State.

Keywords: Creative Tourism, Creative Contents, Global Experience, Entrepreneurship, Business Development.

Submitted : May 26, 2021

Published : June 16, 2021

ISSN: 2507-1076

DOI: $10.24018 /$ ejbmr.2021.6.3.897

Christabel D. Brownson*

Akwa Ibom State University, Nigeria.

(e-mail: christabelbrownson@yahoo.com)

\section{INTRODUCTION}

Tourism was called upon by the World Bank and United Nations World Tourism Organization (UNWTO) to take place in national development of developing Countries [36]. Due to the importance and relevance of tourism, most developing countries are now promoting some brand of tourism tied to its development [37] and Nigeria is no exception. Unlike the oil distribution in the Country, which is centered in a region, tourism resources are spatially distributed in all the geopolitical zones in Nigeria. It is observed that every Local Government Area (L.G.A) in Nigeria has at least one tourism resources. A thorough resource inventory would show the huge potential of tourism in Nigeria. Experts believe that tourism can trigger the much needed socio-economic development in any country including Nigeria. Hence, tourism in Nigeria has the potential of being a supplementary source of revenue for the country if not the major source. It is in this regard that this study set out to investigate the link between creative tourism and the development of businesses in Nigeria specifically in Akwa Ibom State.

\section{CReative Tourism}

Creative tourism is defined in various ways such as a tourism which offers visitors the opportunity to develop their creative potentials through active participation in learning experiences which are the characteristics of the holiday destination where they are undertaken [29]. It is travel directed towards an engaged and authentic experience with participative learning in the arts, heritage or special character of a place and it provides a connection with those who reside in the place and create this living [33]. Kesimoglu [17] asserted that it is a type of tourism that relies on creative resources and creative clusters and delivers creative experiences. Piscitelli [21] stated that it is a tourism that gives the possibility to develop own creative potential through experience linked to the culture of the places in many fields, such as cookery, painting, photography, crafts, and arts holidays. Cabeca et. al [7] claimed it is a type of tourism that develops the tourists' creativity through their active participation in experiences which are characteristics of their destination. Creative tourism is a step forward in cultural tourism and a catalyst of regional and local development [22]. It is an extension of cultural tourism in which consumers seek interactive and dynamic experiences [4]. Hull \& Sassenberg [14] pointed out that it can be seen as a kind of transference of the past into the present and the future via the relationship between local community and tourists. It is a convergence of tourism and the creative economy generating knowledge based creative activities that link producers, consumers, and places by utilizing technology, talent, or skill to generate meaningful intangible cultural products, creative content and experiences [20]. Creative tourism concentrates on image, lifestyles, atmosphere, narratives, and media [25]. It centers around active learning experiences developed in a workshop or more formal 
learning setting [27] and provides visitors with learning experiences, as they sometimes create their personal souvenirs [5]. Creative tourism is increasingly being seen as a means of bringing people together to co-create and to forge new relationships [27]. According to Al-Ababneh [3], Creative tourism consist of a number of creative practices including the place, production and consumption. Marques [19] posited that it is a form of tourism based on experiences and the focus of touristic activity is on the experience itself more than on the service provider or tourist themselves and is also about living in and experiencing cultures different from the home culture of the visitor. Dekker and Tabbers [9] put forward that creative tourism implies that the ultimate goal is to let the tourist be part of the new surroundings of his or her destination. In other words, the tourist becomes part of the creative core of a destination that is, creative tourism involves the creative interactions of policy makers and producers. Since there is no consensus on a particular definition of creative culture, the following concepts can be seen in the above definitions which are considered the key elements of creative tourism:

- Active participation [29], [33], [7];

- Learning experiences/ authentic experience /creative experience [29], [33], [19], [5], [17], [20], [27], [4];

- Development of creative potentials/skills [29], [20], [21];

- Creative content [9], [17], [20], [3];

- Utilizing Technology [17], [20].

Given the above key elements, this study adopts the factors that necessitate creative tourism such as application of skills [29], [20], [21]), absorbing global experience [29], [33], [17], [20], [4], utilizing technologies [17], [20] and creative content [9], [17], [20], [3].

\section{A. Application of Skills}

Richard and Wilson [30] suggested that the development of creative attractions require the acquisition of new skills on the part of the planners and those providing the attraction. As such, those currently employed in the tourism industry and/or the creative sector need to be able to develop the performative, interpretative and pedagogic skills required to stage and facilitate Creativity in Tourism. Remoaldo et al [22] cited that creative tourism gives tourists the opportunity to develop creative potential and skills by being actively involved in the creative processes. Richards [23] posited that, the current movement in society is towards 'skilled consumption', including education, self-development, and creative activities, which depends on developing individual skill and creativity. By developing a skill, people can also increase their level of challenge and therefore the excitement of the activity themselves. Richards [24] added that in creative tourism, the locals themselves become teachers guiding the tourist through their culture either through workshops, open ateliers, events, or cultural itineraries.

\section{B. Absorbing Global Experience}

The development of skills through consumption is also linked with a high level of involvement and absorption in the experience [23]. The idea that tourist as well as destination can be creative in their use of the basic building blocks of tourism experience also opens up new perspectives on the nature of tourism itself. Creative tourism is a form of tourism based on experiences and the focus of touristic activity is on the experience itself more than on the service provider or the tourist themselves [19] and is also about living in and experiencing cultures different from the home culture of the visitor [9]. The conceptualization of the experience includes engaging the five senses in the development process and providing spaces and a flow of activities to allow for creative expression. The experience can then be enriched through cocreation and innovation of new experiences between tourists and locals [32]. Visitors wish to increasingly engage with first-hand genuine experiences, by using simple materials and imagination and even take home unique pieces which they made themselves [15]. Visitors exchange experiences and engage with local people and local culture and are part of the process of co-creation together with them [22]. Creative tourism experiences are not only economically valuable, but may stimulate the development of new ideas, products, and services through the interactions, conversations, and co-creation experiences that occur [8].

\section{Utilizing Technology}

New technologies now play an important role in the way people communicate and live a touristic experience. Technologies enhance the experience and make it easier for visitors to interact and communicate with local people while visiting a destination [30]. The development of new technologies has an impact on the way people appreciate art and the way they look unto other creative businesses. With continuous emergency of new technology, new forms of art expression arise [34]. New media technologies in the form of digital art works are presented within a screen-based electronic, virtual network or mobile domain enhancing the experience of the tourist [6]. New technologies are allowing people to locate creative activities to rural areas, and intangible heritage is becoming a more important aspect of tourism experiences [20].

\section{Creative Content}

Tourism now provides opportunities for tourist to be creative in their destination of stay. Country house hotel now offers add on creativities such as learning how to cook country style dishes, fishing, shooting, mystery weekends, riding (horse riding, car racing among others), playing games (tennis, basket balls, chess, scrabbles, golf), writing, music master classes and other forms of environmental art [30]. One cannot forget that the opportunity to develop creative potential makes competition among tourist destinations fierce due to the growing number of territories that try to compete for international tourists. This forces producers (private and public) to develop initiatives where imagination and fantasy play a relevant role while trying to adjust to tourists' demands [22]. Creative tourism experiences combine different creative content elements and engage with creative lifestyles. Visitors or consumers want to be actively involved in creative experiences and activities. Creative tourism consumers desire to "go where the creativity is" and to directly participate in creation and co-creation activities [28]. Destinations have to identify characteristic creative content and activities that connect with the needs of visitors and residents" [20]. 


\section{BUSINESS DEVELOPMENT}

Business development is defined as the tasks and processes concerning the analytical preparation of potential growth opportunities and the support and monitoring of the implementation of growth opportunities. Tourism is believed to have economic benefits. It is shown to be one of the main factors for economic growth [24]. Creative tourism appears as a key option for development [22]. It is an important system to develop and empower the communities (ibid.). It can help to stimulate local economic, social and cultural development [23]. In Thailand, creative tourism is being used as a means of stimulating community-based tourism development [35]. The economic benefits of tourism lie in the purchasing power generation from revenue through the expenditure of visitors [13]. For example, in Nigeria, the economic impact of tourism on her national economy is estimated at \$280milloin or N36billion. Downstream impact from the "export" revenues of international tourist spending is estimated to generate additional gross revenue of $\$ 224$ million or N29billion [1]. Tourism acts as catalyst for growth of trade and industry and increase in self-employment opportunities like establishing restaurant, kiosk, cybercafé among others which can facilitate livelihood fast more than formal employment [16]. Although there are several indicators of business developments such as increase balance of payment, increase in foreign exchange, and increase employment opportunities among others. This study will focus on employment opportunities.

\section{A. Employment Opportunities}

It is an opportunity to earn income. It is a means of selfrespect and provides an entitlement and command over goods and services. The development of tourism generates new direct and indirect job opportunities and a reduction of deficit in current account while generating more tax revenues for the government for the running of economic activities [2], [10], [18]. The sustained demand for travel and tourism, coupled with its ability to generate a high level of employment continue to prove the importance and value of the sector as a tool for job creation and economic development [11], [12]. Tourism and hospitality industries create many employment opportunities in different areas like accommodations, transportation, attraction sites among others.

\section{RESEARCH METHOD}

Using a descriptive study with a purposive sampling method, 200 entrepreneurs who consisted of craft workers, art galleries makers, hotel owners, food vendors, computer operators, photographers among others were examined at tourist sites in Akwa Ibom State as shown on Table I below:

TABLE I: RESPONDENTS USED FOR THE STUDY

\begin{tabular}{ccc}
\hline S/N & Selected Tourist Centres & Number of Entrepreneurs \\
\hline 1 & Raffia City, Ikot Ekpene & 57 \\
2 & Ibeno Beach, Ibeno & 55 \\
3 & Uta Ewa Beach, Ikot Abasi & 56 \\
4 & Le Meridian Hotel Complex and & 32 \\
\hline
\end{tabular}

Data was collected using a structured questionnaire. Of the 200 questionnaires distributed, only 192 were returned in useable form as such, 192 respondents' responses are used in analyzing the Data from the field work.

\section{ANALYSIS}

This study sought to examine creative tourism and business development. The below tables show the analysis of the study:

TABLE II: APPLICATION OF SKILLS AND EMPLOYMENT OPPORTUNITIES

\begin{tabular}{|c|c|c|c|c|c|c|}
\hline \multirow[t]{2}{*}{$\mathrm{S} / \mathrm{N}$} & \multirow{2}{*}{$\begin{array}{c}\text { Application of Skills } \\
\text { and Employment } \\
\text { Opportunities }\end{array}$} & \multicolumn{5}{|c|}{ Extent of Agreement or Disagreement } \\
\hline & & SA & A & SD & $\mathrm{D}$ & TOTAL \\
\hline 1 & $\begin{array}{l}\text { Ability to add } \\
\text { knowledge learnt } \\
\text { in the production } \\
\text { of art/craftwork } \\
\text { can bring about } \\
\text { more patronage } \\
\text { and in turn ensure } \\
\text { job opportunities }\end{array}$ & $\begin{array}{c}103 \\
(54 \%)\end{array}$ & $\begin{array}{c}76 \\
(39 \%)\end{array}$ & $\begin{array}{c}6 \\
(3 \%)\end{array}$ & $\begin{array}{r}7 \\
(4 \%)\end{array}$ & $\begin{array}{c}192 \\
(100 \%)\end{array}$ \\
\hline 2 & $\begin{array}{l}\text { Application of } \\
\text { skill to products } \\
\text { and services aids } \\
\text { local content to } \\
\text { compete globally } \\
\text { which brings } \\
\text { about job } \\
\text { opportunities }\end{array}$ & $\begin{array}{c}66 \\
(34.3 \%)\end{array}$ & $\begin{array}{c}114 \\
(59.3 \%)\end{array}$ & $\begin{array}{c}8 \\
(4.3 \%)\end{array}$ & $\begin{array}{c}4 \\
(2.1 \%)\end{array}$ & $\begin{array}{c}192 \\
(100 \%)\end{array}$ \\
\hline 3 & $\begin{array}{l}\text { Ability to apply } \\
\text { knowledge to } \\
\text { complete a } \\
\text { specific task give } \\
\text { you edge over } \\
\text { others creating } \\
\text { more job } \\
\text { opportunities }\end{array}$ & $\begin{array}{c}63 \\
(33 \%)\end{array}$ & $\begin{array}{c}97 \\
(50 \%)\end{array}$ & $\begin{array}{c}21 \\
(11 \%)\end{array}$ & $11(6 \%)$ & $\begin{array}{c}192 \\
(100 \%)\end{array}$ \\
\hline
\end{tabular}

Table II above shows the analysis on application of skills and employment opportunities. The table indicates that in the first item on the application of skills and employment opportunities, 103 respondents representing $54 \%$ of the responses strongly agreed to the entrepreneur's ability to add knowledge they had learnt in the production of art/craftwork which can bring about more patronage from tourist ensuring that they create more job opportunities in the process. 76 respondents representing 39\% agreed to the first item on the table while 6 respondents representing $3 \%$ of responses strongly disagreed as well as 7 respondents representing $4 \%$ of responses disagreed to the first item. On the second item on Table II, 66 respondents representing $34.3 \%$ of the responses strongly agreed to the assertion that application of skill to products and services aids local content to compete globally which brings about job opportunities. 114 respondents representing $59.3 \%$ of the responses agreed to the second item with 8 respondents representing $4.3 \%$ of the responses strongly disagreeing to the second while only 4 respondents representing $2.1 \%$ disagreed to the item. 63 respondents representing $33 \%$ of the responses strongly agreed to the third item on Table II which asserts that ability to apply knowledge to complete a specific task give you edge over others creating more job opportunities. 97 respondents 
representing $50 \%$ of the responses agreed to the third item, 21 respondents representing $11 \%$ strongly disagreed to the third item while only 11 respondents representing $6 \%$ of the responses disagreed to the assertion on the third item on Table II. On the whole, the above analysis indicates that there is a higher level of agreement that application of skills can aid generate employment opportunities

TABLE III: ABSORBING GLOBAL EXPERIENCE AND EMPLOYMENT

\begin{tabular}{|c|c|c|c|c|c|c|c|}
\hline \multicolumn{7}{|c|}{ OPPORTUNITIES } & \\
\hline \multirow[b]{2}{*}{$\mathrm{S} / \mathrm{N}$} & Absorbing Global & \multicolumn{5}{|c|}{ Extent of Agreement or Disagreement } & \\
\hline & Employment & SA & A & SD & $\mathrm{D}$ & TOTAL & \\
\hline 1 & $\begin{array}{l}\text { Applying what is } \\
\text { done in another } \\
\text { country can promote } \\
\text { business and as well } \\
\text { create job } \\
\text { opportunities }\end{array}$ & $\begin{array}{c}113 \\
(59 \%)\end{array}$ & $\begin{array}{c}66 \\
(34 \%)\end{array}$ & $\begin{array}{c}5 \\
(3 \%)\end{array}$ & $\begin{array}{c}8 \\
(4 \%)\end{array}$ & $\begin{array}{c}192 \\
(100 \%)\end{array}$ & 2 \\
\hline 2 & $\begin{array}{l}\text { Different practices } \\
\text { such as cultural } \\
\text { heritage, food and } \\
\text { customs bring } \\
\text { people to a } \\
\text { particular place thus } \\
\text { generate } \\
\text { employment } \\
\text { opportunities }\end{array}$ & $\begin{array}{c}100 \\
(52 \%)\end{array}$ & $\begin{array}{c}80 \\
(42 \%)\end{array}$ & $\begin{array}{c}6 \\
(3 \%)\end{array}$ & $\begin{array}{c}6 \\
(3 \%)\end{array}$ & $\begin{array}{c}192 \\
(100 \%)\end{array}$ & 3 \\
\hline 3 & $\begin{array}{lr}\text { Introduction } & \text { of } \\
\text { foreign } & \\
\text { goods/services } & \text { can } \\
\text { ensure tourist } & \text { needs } \\
\text { satisfied, increase } & \text { patronage, } \\
\text { promote } & \text { and } \\
\text { opportunities } & \text { job }\end{array}$ & $\begin{array}{c}108 \\
(56 \%)\end{array}$ & $\begin{array}{c}74 \\
(39 \%)\end{array}$ & $\begin{array}{c}6 \\
(3 \%)\end{array}$ & $\begin{array}{c}4 \\
(2 \%)\end{array}$ & $\begin{array}{c}192 \\
(100 \%)\end{array}$ & \\
\hline
\end{tabular}

Table III above shows the analysis on absorbing global experience and employment opportunities. The table indicates that in the first item on the application of skills and employment opportunities, 113 respondents representing $59 \%$ of the responses strongly agreed to the assertion that ability to apply what is done in another country can promote businesses as well as create job opportunities. 66 respondents representing $34 \%$ agreed to the first item on the table while 5 respondents representing $3 \%$ of responses strongly disagreed as well as 8 respondents representing $4 \%$ of responses disagreed to the first item. On the second item on Table III, 100 respondents representing 52\% of the responses strongly agreed to the assertion that different practices such as cultural heritage, food and customs bring people to a particular place thus generate employment opportunities. 80 respondents representing $42 \%$ of the responses agreed to the second item with 6 respondents representing $3 \%$ of the responses strongly disagreeing to the second item while only 6 respondents representing 3\% disagreed to the item. 108 respondents representing $56 \%$ of the responses strongly agreed to the third item on Table III which asserts that introduction of foreign goods/services can ensure tourist needs are satisfied, increase patronage, and promote job opportunities. 74 respondents representing 39\% of the responses agreed to the third item, 6 respondents representing 3\% strongly disagreed to the third item while only 4 respondents representing $2 \%$ of the responses disagreed to the assertion on the third item on Table III. On the whole, the above analysis indicates that there is a higher level of agreement that absorbing global experience can aid generate employment opportunities

TABLE IV: UTILIZING TECHNOLOGY AND EMPLOYMENT OPPORTUNITIES

\begin{tabular}{|c|c|c|c|c|c|c|}
\hline \multirow[t]{2}{*}{$\mathrm{S} / \mathrm{N}$} & \multirow{2}{*}{$\begin{array}{l}\text { Utilizing Technology } \\
\text { and Employment } \\
\text { Opportunities }\end{array}$} & \multicolumn{5}{|c|}{ Extent of Agreement or Disagreement } \\
\hline & & SA & A & SD & $\mathrm{D}$ & TOTAL \\
\hline 1 & $\begin{array}{l}\text { Utilization } \\
\text { emerging } \\
\text { technologies now } \\
\text { brings effectiveness } \\
\text { and efficiency in } \\
\text { art/craftwork } \\
\text { production which in } \\
\text { turn brings job } \\
\text { opportunities }\end{array}$ & $\begin{array}{c}98 \\
(51 \%)\end{array}$ & $\begin{array}{c}81 \\
(42 \%)\end{array}$ & $\begin{array}{c}8 \\
(4 \%)\end{array}$ & $\begin{array}{c}5 \\
(3 \%)\end{array}$ & $\begin{array}{c}192 \\
(100 \%)\end{array}$ \\
\hline 2 & $\begin{array}{l}\text { Technologies make it } \\
\text { easier for visitors to } \\
\text { interact, } \\
\text { communicate with } \\
\text { local people and as } \\
\text { well aid digital } \\
\text { promotion rof } \\
\text { art/craftworks which } \\
\text { create } \\
\text { opportunities job }\end{array}$ & $\begin{array}{c}88 \\
(46 \%)\end{array}$ & $\begin{array}{c}92 \\
(48 \%)\end{array}$ & $\begin{array}{c}8 \\
(4 \%)\end{array}$ & $\begin{array}{c}4 \\
(2 \%)\end{array}$ & $\begin{array}{c}192 \\
(100 \%)\end{array}$ \\
\hline 3 & $\begin{array}{l}\text { Development of new } \\
\text { technologies has an } \\
\text { impact on how tourist } \\
\text { appreciate our } \\
\text { artwork thereby } \\
\text { creating openings for } \\
\text { more jobs }\end{array}$ & $\begin{array}{c}69 \\
(36 \%)\end{array}$ & $\begin{array}{c}94 \\
(49 \%)\end{array}$ & $\begin{array}{c}16 \\
(8 \%)\end{array}$ & $\begin{array}{c}13 \\
(7 \%)\end{array}$ & $\begin{array}{c}192 \\
(100 \%)\end{array}$ \\
\hline
\end{tabular}

Table IV above shows the analysis on utilizing Technology and employment opportunities. The table indicates that in the first item on utilizing Technology and employment opportunities, 98 respondents representing 51\% of the responses strongly agreed to the assertion that Utilization of emerging technologies now brings effectiveness and efficiency in art/craftwork production which in turn brings job opportunities. 81 respondents representing $42 \%$ agreed to the first item on the table while 8 respondents representing $4 \%$ of responses strongly disagreed as well as 5 respondents representing $3 \%$ of responses disagreed to the first item. On the second item on Table IV, 88 respondents representing $46 \%$ of the responses strongly agreed to the assertion that Technologies make it easier for visitors to interact, communicate with local people and as well aid digital promotion of art/craftworks which create job opportunities. 92 respondents representing $48 \%$ of the responses agreed to the second item with 8 respondents representing $4 \%$ of the responses strongly disagreeing to the second while only 4 respondents representing $2 \%$ disagreed to the item. 69 respondents representing $36 \%$ of the responses strongly agreed to the third item on Table IV which asserts that Development of new technologies has an impact on how tourist appreciate our artwork thereby creating openings for more jobs. 94 respondents representing $49 \%$ of the responses agreed to the third item, 16 respondents representing $8 \%$ strongly disagreed to the third item while only 13 respondents representing $7 \%$ of the responses disagreed to the assertion on the third item on Table IV. On the whole, the above analysis indicates that there is a higher level of agreement that utilizing technology can aid generate employment opportunities 
European Journal of Business and Management Research www.ejbmr.org

TABLE V: CREATIVE CONTENTS AND EMPLOYMENT OPPORTUNITIES

\begin{tabular}{|c|c|c|c|c|c|c|}
\hline \multirow{2}{*}{$\mathrm{S} / \mathrm{N}$} & \multirow{2}{*}{$\begin{array}{c}\text { Creative contents and } \\
\text { employment } \\
\text { opportunities }\end{array}$} & \multicolumn{5}{|c|}{ Extent of agreement or disagreement } \\
\hline & & SA & A & SD & D & TOTAL \\
\hline 1 & $\begin{array}{l}\text { Awareness of } \\
\text { innovative service } \\
\text { brings in different } \\
\text { group of people every } \\
\text { day thus encourages } \\
\text { business development } \\
\text { and job opportunities }\end{array}$ & $\begin{array}{c}102 \\
(53 \%)\end{array}$ & $\begin{array}{c}77 \\
(40 \%)\end{array}$ & $\begin{array}{c}7 \\
(4 \%)\end{array}$ & $\begin{array}{c}6 \\
(3 \%)\end{array}$ & $\begin{array}{c}192 \\
(100 \%)\end{array}$ \\
\hline 2 & $\begin{array}{l}\text { Using creative ideas, } \\
\text { innovative strategy to } \\
\text { promote our business } \\
\text { attract more customers } \\
\text { thus encourages job } \\
\text { opportunities }\end{array}$ & $\begin{array}{c}82 \\
(43 \%)\end{array}$ & $\begin{array}{c}98 \\
(51 \%)\end{array}$ & $\begin{array}{c}10 \\
(5 \%)\end{array}$ & $\begin{array}{c}2 \\
(1 \%)\end{array}$ & $\begin{array}{c}192 \\
(100 \%)\end{array}$ \\
\hline 3 & $\begin{array}{l}\text { The introduction of } \\
\text { creative content in } \\
\text { tourism such as; } \\
\text { learning how to play } \\
\text { tennis, writing or } \\
\text { music master classes } \\
\text { and others, other than } \\
\text { the traditional } \\
\text { businesses of } \\
\text { art/craftwork creation } \\
\text { can connect local } \\
\text { tourist centres globally } \\
\text { and thereby bring } \\
\text { about job opportunities }\end{array}$ & $\begin{array}{c}58 \\
(30 \%)\end{array}$ & $\begin{array}{c}102 \\
(53 \%)\end{array}$ & $\begin{array}{c}17 \\
(9 \%)\end{array}$ & $\begin{array}{c}15 \\
(8 \%)\end{array}$ & $\begin{array}{c}192 \\
(100 \%)\end{array}$ \\
\hline
\end{tabular}

Table $\mathrm{V}$ above shows the analysis on creative contents and employment opportunities. The table indicates that in the first item on the creative contents and employment opportunities, 102 respondents representing 53\% of the responses strongly agreed to the assertion that awareness of innovative service brings in different group of people every day thus encourages business development and job opportunities. 77 respondents representing $40 \%$ agreed to the first item on the table while 7 respondents representing $4 \%$ of responses strongly disagreed as well as 6 respondents representing $3 \%$ of responses disagreed to the first item. On the second item on Table V, 82 respondents representing $43 \%$ of the responses strongly agreed to the assertion that Using creative ideas, innovative strategy to promote our business attract more customers thus encourages job opportunities. 98 respondents representing $51 \%$ of the responses agreed to the second item with 10 respondents representing $5 \%$ of the responses strongly disagreeing to the second while only 2 respondents representing $1 \%$ disagreed to the item. 58 respondents representing $30 \%$ of the responses strongly agreed to the third item on Table $\mathrm{V}$ which asserts that the introduction of creative content in tourism such as learning how to play tennis, writing or music master classes and others, other than the traditional businesses of art/craftwork creation can connect local tourist centers globally and thereby bring about job opportunities. 102 respondents representing 53\% of the responses agreed to the third item, 17 respondents representing 9\% strongly disagreed to the third item while only 15 respondents representing $8 \%$ of the responses disagreed to the assertion on the third item on Table V. On the whole, the above analysis indicates that there is a higher level of agreement that creative contents can aid generate employment opportunities.

\section{DISCUSSION OF FINDINGS}

The study sought to examine Creative tourism and the development of businesses in Akwa Ibom State. From the analysis of the variables of creative tourism and business development above, the results found are discussed as follows:

\section{A. Application of Skills and Employment Opportunities}

The result of the analysis as seen on Table II indicated a higher level of agreement that application of skills can aid generate employment opportunities. This result aligns with the views of Richard and Wilson [30] who suggested that the development of creative attractions require the acquisition of new skills on the part of the planners and those providing the attraction. As such, those currently employed in the tourism industry and/or the creative sector need to be able to develop the performative, interpretative and pedagogic skills required to stage and facilitate Creativity in Tourism. The result also aligns with Richards [23] who posited that by developing a skill, people can also increase their level of challenge and therefore the excitement of the activity themselves. The result also hints that the locals with their acquired skills in crafts and other areas are fit to teach and guide the tourist in their chosen field according to Richards [24].

\section{B. Absorbing Global Experience and Employment Opportunities}

The result of the analysis as seen on Table III indicated a higher level of agreement that absorbing global experience can aid generate employment opportunities. The result aligns with the idea that creative tourism is about living in and experiencing cultures different from the home culture of the visitor [9] as the entrepreneurs' exhibit both local and foreign products/services and attractions which from their responses attract more patronage from tourist as well as aiding to generate employment opportunities. The provision of different cultural heritage, foods and other services help to engage some of the five senses of the tourist in terms of sight, touch and taste which aligns with Wiyana et al [35]'s conceptualization of the experience. The use of foreign products by the entrepreneurs shows their interaction with visitors over the years which indicated a sort of exchange of experiences [22] and ideas which had led to the development of such foreign products due to interactions, conversations and co-creation experiences that occurred [8].

\section{Utilizing Technology and Employment Opportunities}

The result of the analysis as shown on Table IV indicated that that there is a higher level of agreement that utilizing technology can aid generate employment opportunities. The result aligns with the fact that technologies enhance the experience and make it easier for visitors to interact and communicate with local people while visiting a destination [30], [6]. The result also aligns with the idea that new technologies have an impact on the way people appreciate art and the way they look unto other creative businesses [34].

\section{Creative Content and Employment Opportunities}

The result of the analysis on Table V shows that there is a high level of agreement that creative content can aid in the generation of employment opportunities. The result agrees 
with the views of Richards and Wilson [30], OECD [20] and Richards [28] in that awareness of innovative services bring in people to the tourism site that is, ' consumers desire to go where the creativity is' [28] and such creative services attract global visitors to the tourist site with the locals who show case such creativity [20] hence, different creative activities such as cooking country style dishes, playing tennis, fishing, music writing among others are learnt and taught. Tourism now provides opportunities for tourist to be creative in their destination of stay -creatively [30].

\section{CONCLUSION}

This study sought to investigate the link between creative tourism and business development in Akwa Ibom State with investigations carried out in 4 major tourist sites in the State. The results indicated very highly level of positive agreement that the variables of creative tourism such as application of skills, absorbing global experience, utilizing technologies and the use of creative contents does aid in the development of businesses in the state especially in the area of generating employment opportunities for local entrepreneurs. The results of the study are supported by extant literature as discussed in the discussion of findings. These shows that the government should develop more tourist sites in the State to help those who have acquired skills to utilize the opportunities provided by the tourist sites to display their creative products and services which will in turn attract patronage from visitors to the site enabling them to be gainfully employed, generate employment for others and contribute to the overall business development in the State. Future studies can investigate further in this area with the focus on the visitors to the tourist site. This can help understand further if their engagement with the activities of the providers of tourist attractions and services at the tourist site has helped in enhancing their skill development in local craft/culture, in enhancing their experiences among other variables.

\section{REFERENCES}

[1] Abubakar, I. Z. (2014) The Economic Contribution of Tourism in Nigeria and the Strategies for Increasing the Contribution in the Future, Retrieved 24/03/2021 from https://www.academic.edu/5936943/economic.

[2] Adeleye, N., Osabuohien, E., Bowale, e., Mathew, O., \& Oduntan E. (2017) Financial Reforms and Credit Growth in Nigeria: Empirical Insights from ARDL and ECM Techniques. International Review of Applied Economics, 32 (6)1-14.

[3] Al-Ababneh MM (2017) Creative Tourism. Journal of Tourism \& Hospitality 6: 282. doi: 10.4172/2167-0269.1000282.

[4] Amaral, M. \& Rodigues, A. (2020) The Importance of Social Media for the Improvement of the Tourist Experience offered by Rural Tourism Enterprises. The Case of Alentejo. In Celia Ramos, Claudia Almeida, \& Paula Fernandes (Eds.) Handbook of Research on Social Media Applications for the Tourism and Hospitality Sector, (PP.309333). Hershey, PA. IGI Global.

[5] Angeloni, S. (2013). Cultural tourism and well-being of the local population in Italy. Theoretical and Empirical Researches in Urban Management, 8(3), pp. 17-31.

[6] Arts Council of New Zealand, 2011). Do my arts look good on this? Media arts and digital platforms, Retrieved October, 1, 2012, from http://www.creativenz.govt.nz/asssts/paperelip/publication_document ations/documents/123/original/do my arts look good on this final.pdf?1322079831.

[7] Cabeca, S. M., Goncalves, A. R., Marques, J. F. \& Tavares, M. (2020) Creative Tourism as an Inductor of Co-creation Experiences. The
CREATOUR Project in the Algarve. In Pinto P., Guerreiro M., Editors. Handbook of Research on Resident and Tourist Perspectives on Travel Destinations. IGI Global; Pennsylvania: 2020. DOI:10.4018/978-17998-3156-3.ch013

[8] CREATOUR (2017). The State of the Art in Creative Tourism. Call for Projects, CREATOUR.

[9] Den Dekker, T., \& Tabbers, M. (2012). From Creative Crowds to Creative Tourism: A search for creative tourism in small and medium sized cities. Journal of Tourism Consumption and Practice, 4(2), 129132.

[10] Dogru, T. \& Bulut, U. (2018) Is Tourism an Engine for Economic Recovery? Theory and Empirical Evidence. Tourism Management, 67, 425-434.

[11] Dwyer, L. \& Kim, C. (2003) Destination Competitiveness: Determinants and Indicators, Current Issues of Tourism, Vol.6. No.5, pp. 369-414.

[12] Ejemeyovwi, J.O., Osabuohien, E. S. \& Osabohien, R. (2018) ICT Investments Human Capital Development and Institutions in ECOWAS, International Journal of Economics and Business Research, 15 (4) 4630-474.

[13] Ghosh, B. (2011) Tourism and Travel Management. Bengaluru: VikasPublishing House Put Ltd.

[14] Hull, J., \& Sassenberg, U. (2012). Creating new cultural visitor experiences on islands: challenges and opportunities. Journal of Tourism Consumption and Practice, 4(2), 91-110.

[15] Hung, W.-L., Lee, Y.-J., \& Huang, P.-H. (2016). Creative experiences, memorability and revisit intention in creative tourism. Current Issues in Tourism, 19(8), 763-770. doi: 10.1080/13683500.2013.877422.

[16] Ijeoma, E. (2010) NTDC Has contributed to the Nation's EconomyRunsewe: Tourism News Nigerian. Retrieved Feb. 23, 2015 from http://tourism-news-nigeria.blogspot.com/2010/10/ntdc-hascontributed-to-nations-economy.html.

[17] Kesimoglu, A. (2014) Entertainment and Food Tourism in the Backdrop of late modernity and a reflection on Turkey. In R. Ozturk (Eds), Handbook of Research on the Impact of Culture and Society on the Entertainment Industry, (pp. 39-56) IGI Global. DOI: 10.4018/978-1-4666-6190.5.ch003.

[18] Mathew, A. O., Fasina, F. F., Olowe, O. \& Adegboye, F. B. (2010) Empirical Modeling of the Impact of Financial Innovation on the demand for money in Nigeria. International Research Journal of Finance and Economics, 58, 73-90.

[19] Marques, L. (2012) Boosting potential creative tourism resources: the case of Siby (Mali). Journal of Tourism Consumption and Practice, 4(2), p.111-128.

[20] OECD (2014). Tourism and the Creative Economy. Paris: OECD.

[21] Piscitelli, (2019) Promotion of Heritage Tourism through Branding and Graphic Communication. In Conservation and Promotion of Heritage Tourism - Alvarez-Garcia, J.; Rama, C.R.; Dixit, M., Hira, P. and Poonia, M. (2019) DOI: 10.4018/978-1-5225-6283-2.ch004.

[22] Remoaldo, P.C.; Matos, O.; Freitas, I.; Gôja, R.; Alves, J.; Ribeiro, V., Pereira, M.; Xavier, C. (2020), "An international overview of certified practices in creative tourism in rural and urban territories", Journal of Hospitality \& Tourism Research. DOI: https://journals.sagepub.com/doi/full/10.1177/1096348020950792.

[23] Richards, G. (2009) Creative tourism and local development. In: Wurzburger, R., Pattakos, A. and Pratt, S. (eds) Creative Tourism: A Global Conversation. Santa Fe: Sunstone Press, pp. 78-90.

[24] Richards, G. (2011). Creativity and Tourism: The State of the Art. Annals of Tourism Research, 38(4), 1225-1253.

[25] Richards, G. (2014). Creativity and tourism in the city. Current Issues in Tourism, 17(2), 119-144.

[26] Richards, G. (2017). The development of creative tourism in Asia. In C. Silver, L. Marques, H. Hanan, \& I. Widiastuti (Eds.). Imagining Experience: Creative Tourism and the making of Place (pp. ix-xiv). New York: Springer Science+Business Media.

[27] Richard, (2018) Panorama of Creative Tourism Around the World, Conference Paper, Presented at the Seminario Internacional de Turismo Criativo, Cais do Sertao, Recife, Brazil, $7^{\text {th }}$ December, 2018.

[28] Richards, G. (2019). Creative tourism: Opportunities for smaller places? Tourism and Management Studies, 15 (Special Issue), 7-10.

[29] Richards, G., \& Raymond C. (2000). Creative Tourism. ATLAS News, 23, $16-20$

[30] Richards, G., \& Wilson, J. (2007). The creative turn in regeneration: Creative spaces, spectacles and tourism in cities. In M. Smith (Ed.) Tourism, Culture and Regeneration (pp. 12-24). London: Routledge.

[31] Souca, M.L. (2019). Revitalizing Rural Tourism through Creative Tourism: The Role and Importance of the Local Community, Marketing from Information to Decision Journal, Volume 2, Issue 2, pp. 43-50. 
[32] Wiyana, T., Bahri, A. S., Zulkarnain, A. \& Tomahuw, R. (2018) Basic of Creative Tourism: Batik as a Creative Industry, Advances in Economics, Business and Management Research, Volume 168, p.1923.

[33] UNESCO (2006) "Towards Sustainable Strategies for Creative Tourism,"Discussion Report of the planning meeting for 2008 International Conference on Creative Tourism Sante $\mathrm{Fe}$, New Mexico.http://unesdoc.unesco.org/images/0015/001598/159811E.pdf. Accessed on 23.10.2016.

[34] White, P. (2010) Creative Industries in a Rural Region: Creative Sector in the Western Region of Ireland. Creative Industries Journal 3(1), pp.79-88.

[35] Wisansing, J. (2015). Redesign Tourism. Bangkok: DASTA.

[36] World Bank (2002) Millennium development goals: Eradicate Extreme Poverty and Hunger. Retrieved on September 20, 2012, from http://www.developmentgoals.org/poverty/htm.

[37] Yunis, E. (2004) Sustainable Tourism and Poverty Alleviation. Paper Presented at the World Bank ABCDE Conference-Europe.Brussels. $10^{\text {th }}$ May, 2004.

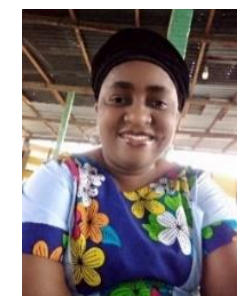

Dr. Christabel Brownson holds a B. Sc in Banking and Finance from University of Uyo, Uyo, Akwa Ibom State, Nigeria, M. Sc in Entrepreneurship and Innovation and $\mathrm{PhD}$ in Entrepreneurship both at the University of Essex, Essex, England. She is a knowledge facilitator and specializes in motivating the entrepreneurial individuals to proactive value venture creation. She is a member of the Institute of Entrepreneurs, Nigeria, and an Associate of the British Advance Higher Education Academy. Her research interest covers Entrepreneurial Culture, New Venture Creation, Entrepreneurship Education, Nigerian Entrepreneurship and Policy Effectiveness. She has several publications to her credit in international journals. 